\title{
PENGARUH PEMBERIAN EKSTRAK ETIL ASETAT BUAH DEWANDARU (Eugenia uniflora L.) TERHADAP GAMBARAN HISTOPATOLOGI HATI MENCIT YANG DIINDUKSI KARBON TETRAKLORIDA $\left(\mathrm{CCl}_{4}\right)$
}

\author{
(EFFECT OF ETHYL ACETATE EXCTRACT OF DEWANDARU FRUIT (Eugenia \\ uniflora L.) ON MICE HEART HISTOPATHOLOGY INDUCED BY CARBON \\ TETRACHLORIDE (CCL4))
}

\author{
PUGUH SANTOSO $^{1 \bullet}$, PUTU ERA SANDHI KUSUMA YUDA ${ }^{1}$ \\ ${ }^{1}$ Akademi Farmasi Saraswati Denpasar, Jalan Kamboja No. 11 A, Denpasar, Bali
}

\begin{abstract}
Abstrak: Tanaman dewandaru (Eugenia Uniflora L.) telah dimanfaatkan oleh masyarakat sebagai obat tradisional. Karbon tetraklorida $\left(\mathrm{CCl}_{4}\right)$ merupakan zat kimia yang bersifat toksik terhadap hepar. Metabolisme $\mathrm{CCl} 4$ menghasilkan radikal bebas $\mathrm{CCl} 3$ - yang dapat mengakibatkan kerusakan pada sel hati. Penelitian ini bertujuan untuk mengetahui efek ekstrak etil asetat buah dewandaru pada histopatologi hati mencit yang diinduksi dengan karbon tetraklorida. Penelitian ini merupakan penelitian eksperimental dengan randomized control group post test only design, menggunakan sampel 15 ekor mencit yang dibagi menjadi tiga kelompok. Kelompok kontrol negatif diberi $\mathrm{CCl}_{4} 1,3 \%$ selama 7 hari pada hari ke 4, kemudian diberi $\mathrm{CCl}_{4} 1,3 \%$ dan ekstrak etil asetat buah dewandaru dengan dosis $0,5 \mathrm{mg} / \mathrm{g} \mathrm{BB}$ sebanyak $1 \mathrm{ml}$ secara bersamaan selama 7 hari, diberi $\mathrm{CCl}_{4}$ 1,3\% dan ekstrak etil asetat buah dewandaru dengan dosis $1 \mathrm{mg} / \mathrm{g}$ BB sebanyak $1 \mathrm{ml}$ secara bersamaan selama 7 hari. Pada hari ke-11 mencit dikorbankan dan dibedah untuk diambil hatinya, pembuatan preparat histopatologi, dan pemeriksaan histopatologi hati mencit. Data hasil pemeriksaan dianalisis secara deskriptif kualitatif. Dari hasil penelitian dapat disimpulkan bahwa gambaran histopatologi hati mencit yang diinduksi karbontetraklorida dan diberikan ekstrak etil asetat buah dewandaru dapat mengurangi degenerasi melemak dengan memperkecil vakuola-vakuola lemak didalam sitoplasma sel hati. Namun, nekrosis pada kelompok kontrol dan kelompok perlakuan ekstrak etil asetat buah dewandaru sudah sebagian menunjukkan adanya perubahan pada sel hati mencit.
\end{abstract}

Kata Kunci: ekstrak etil asetat buah dewandaru, histopatologi hati, karbon tetraklorida, mencit

\begin{abstract}
Dewandaru plant (Eugenia uniflora L.) has been used by people as a traditional medicine. Carbon tetrachloride $(\mathrm{CCl} 4)$ is a chemical that is toxic to the liver. $\mathrm{CCl} 4$ metabolism $\mathrm{CCl} 3$ - generate free radicals that can cause damage to liver cells. This study aims to determine the effect of ethyl acetate extract of the fruit on a histopathological dewandaru liver of mice induced by carbon tetrachloride. This study was an experimental study with post-test only control group design, using a sample of 15 mice were divided into three groups. The negative control group was given $\mathrm{CCl}_{4} 1.3 \%$ for 7 days on day 4 , and then by $1.3 \% \mathrm{CCl}_{4}$ and ethyl acetate extracts of fruit dewandaru with a dose of $0.5 \mathrm{mg} / \mathrm{g}$ of $1 \mathrm{ml}$ concurrently for 7 days, by $\mathrm{CCl}_{4} 1.3 \%$ and the ethyl acetate extract fruit dewandaru a dose of $1 \mathrm{mg} / \mathrm{g}$ of $1 \mathrm{ml}$ concurrently for 7 days. On day 11 mice were sacrificed and dissected to take his heart, making preparations for histopathology, and histopathologic examination liver of mice. Data examination results were analyzed descriptively qualitative.

From the research, it can be concluded that the image of mice induced liver histopathology Carbon tetrachloride and given the ethyl acetate extract dewandaru fruit can reduce the degeneration of vacuoles with far-fat vacuoles in the cytoplasm of liver cells. However, necrosis in the control group and the treatment group ethyl acetate extract of the fruit dewandaru already partly indicate a change in liver cells of mice.
\end{abstract}

Keywords: carbon tetrachloride, ethyl acetate extract fruit dewandaru, liver histopathology, mice

\footnotetext{
• email korespondensi: farmazi.sp@gmail.com
} 


\section{PENDAHULUAN}

Pada masa globalisasi saat ini, banyak perubahan yang terjadi di Negara Indonesia. Perubahan tersebut terjadi pada gaya hidup mereka yang mengikuti gaya hidup orang barat, seperti misalnya mengkonsumsi minuman beralkohol. Mengkonsumsi minuman beralkohol berlebih selalu menimbulkan resiko meskipun telah diusahakan untuk menekannya sekecil mungkin, namun pengaruh toksik dari suatu zat kimia merupakan resiko yang dapat timbul.

Salah satu contoh organ tubuh yang dirusak adalah hepar. Hepar adalah organ yang berperan dalam metabolisme berbagai macam nutrien yang diserap dari saluran cerna (Nurdjaman, dkk., 2001). Hepar merupakan organ terbesar dengan berat $1,2-1,8 \mathrm{~kg}$ atau kurang lebih $25 \%$ berat badan orang dewasa, menempati sebagian besar kuadran kanan atas abdomen, dan merupakan pusat metabolisme tubuh dengan fungsi yang sangat kompleks (Amirudin, 2007). Fungsi dasar hepar dibagi menjadi fungsi vaskular untuk menyimpan dan menyaring darah, fungsi metabolisme yang berhubungan dengan sebagian besar sistem metabolisme tubuh, dan fungsi sekresi serta eksresi yang berperan membentuk empedu yang mengalir melalui saluran empedu ke saluran cerna (Guyton dan Hall, 1997). Kerusakan pada sel hepar akibat obat - obatan dan zat kimia dapat berupa nekrosis sel hepar (hepatosit), kolestasis, gangguan sistesis protein, dan terjadinya akumulasi lemak dalam sel (steatosis) (Klaassen, 1981). Derajat kerusakan sel-sel hati tergantung dari perubahan degenerasi yang terjadi pada organ tersebut. Tipe awal degenerasi pada sel hati berupa degenerasi hidrofik, kemudian berlanjut menjadi degenerasi melemak, sebelum akhirnya sel tersebut mengalami kematian atau nekrosis (Kardena \& Winaya, 2011).

Hepar mempunyai fungsi yang vital, terutama untuk metabolisme tubuh; dan salah satu penyakit yang paling sering menyerang hepar adalah hepatitis. Hepatitis merupakan suatu peradangan difus pada jaringan hepar yang dapat disebabkan oleh berbagai sebab seperti virus, bakteri, parasit, zat - zat kimia, dan obat - obatan dengan manifestasi klinis yang serupa (Hadi, 2002).

Selain alkohol yang dapat merusak hepar, zat kimia lainnya yaitu karbon tetraklorida $\left(\mathrm{CCl}_{4}\right)$. $\mathrm{CCl}_{4}$ merupakan zat kimia yang bersifat toksik, namun masih banyak digunakan terutama dalam industri bahan pendingin, alat pemadam kebakaran, agricultural fumigant, pestisida, cat, tinta, sebagai bahan pelarut aspal, karet, minyak, dan lemak, sebagai bahan tambahan pada bensin serta pembuatan semikonduktor (Fouw \& WHO, 1999).

Banyak obat-obat yang tersebar di pasaran dengan brand yang berbeda untuk penyakit hepatitis ini, tetapi efek samping kedepannya bila rutin mengkonsumsi obat non herbal tersebut dapat pula merusak organ tubuh lainnya. Sehingga masyarakat Indonesia masih terus berusaha membudidayakan tanaman obat. Mengingat pengobatan dengan tanaman obat lebih alami, lebih relatif aman, dan lebih terjangkau harganya. Salah satu tanaman obat yang dapat dimanfaatkan dalam penelitian ini adalah dewandaru. Daun dan buah dewandaru secara empiris digunakan sebagai obat penurun panas dan sakit perut (Suhendi, dkk, 2011). Pada Brazilian folk medicine, disebutkan bahwa daun Eugenia uniflora digunakan sebagai antidiare, diuretik, antirematik, anti-febrile, dan antidiabetik (Santos dkk., 2010). Kandungan senyawa kimia dari tanaman ini antara lain vitamin $\mathrm{C}$, antosianin, saponin, flavonoid dan tanin (Hutapea, 1994; Einbond, dkk, 2004). Penelitian mengenai aktivitas dewandaru yang telah dilakukan diantaranya, pada ekstrak daun dan batangnya sebagai antibakteri (Khotimah, 2004., Oliveira, dkk, 2008). Selain itu, ekstrak daun dewandaru dapat berfungsi sebagai antiradikal yang disebabkan karena adanya senyawa flavonoid (Utami, dkk, 2005). Hasil uji fitokimia buah dewandaru menunjukkan adanya alkaloid, glikosida, flavonoid, tanin, saponin, terpenoid dan daging buah dewandaru (Eugenia Uniflora L.) memiliki tingkat antioksidan yang tinggi (Onwudiwe, dkk, 2010). Salah satu cara untuk melihat kerusakan pada hati mencit yang diberikan karbon tetraklorida yaitu dengan pemeriksaan histopatologi. Pemeriksaan histopatologi dapat melihat secara langsung morfologi dan struktur jaringan sehingga dapat menentukan perubahan dan derajat kerusakan pada organ terkait (Gibson, 2014).

Berdasarkan pemaparan diatas dapat dirumuskan permasalahan sebagai berikut: Apakah pemberian ekstrak etil asetat mempunyai efek hepato protektor dilihat dari gambaran pemeriksaan histopatologi hati mencit yang diinduksi karbon tetraklorida?

\section{BAHAN DAN METODE}

Penelitian ini merupakan penelitian eksperimental dengan randomizied control group 
post test only design yang menggunakan tikus galur wistar sebagai hewan percobaan yang diperoleh dari Pengembangan dan Pemeliharaan Hewan Jl. Pulau Moyo No.15 Perum Telkom No.10A.

Bahan tanaman yang digunakan untuk penelitian ini adalah buah dewandaru (Eugenia uniflora L.). Di dapat dari Desa Purwoharjo Banyuwangi Jawa Timur Maret 2016. Bahan lain yang digunakan adalah 15 ekor mencit jantan, pelarut etil asetat, pakan ayam 594, karbon tetraklorida $\left(\mathrm{CCl}_{4}\right)$, minyak zaitun, CMC 0,5\%, larutan buffer formalin 10\%, parafin cair, larutan hematoxilin dan larutan eosin.

\section{Pembuatan Ekstrak Etil Asetat Buah Dewandaru}

Buah dewandaru yang sudah masak berwarna merah marun dicuci bersih dan dipotong menjadi irisan tipis tipis kemudian dikeringkan menggunakan oven pada suhu $40^{\circ} \mathrm{C}$ selama beberapa hari hingga semua irisan buah menjadi kering kemudian dihancurkan menggunakan blender. Serbuk buah dewandaru ditimbang sebanyak 18,60 g dan dimaserasi menggunakan pelarut etil asetat sebanyak $100 \mathrm{ml}$ dalam toples tertutup rapat, terlindungi dari cahaya. Setelah masuk ketahap filtrasi, akan diperoleh filtrat dan residu. Filtrat yang didapatkan diuapkan dengan rotary evavorator pada suhu $40^{\circ} \mathrm{C}$ sehingga akhirnya diperoleh ekstrak kering.

\section{Pembuatan Larutan CMC 0,5\%}

Sebanyak 0,25 g CMC ditimbang lalu dikembangkan dalam $5 \mathrm{ml}$ air hangat selama 5 menit di dalam beaker glass. Setelah mengembang larutan CMC diaduk sampai homogen, setelah itu ditambahkan aquadest sampai $50 \mathrm{ml}$.

\section{Pembuatan Larutan $\mathrm{CCl}_{4}$}

Larutan $\mathrm{CCl}_{4}$ yang diperlukan untuk membuat Konsentrasi 1,3\%

$$
\begin{array}{ll}
\mathrm{V}_{1} \times \mathrm{M}_{1} & =\mathrm{V}_{2} \times \mathrm{M}_{2} \\
\mathrm{~V}_{1} \times 100 \% & =\frac{100 \mathrm{ml} \times 1,3 \%}{100 \%} \\
& =1,3 \mathrm{ml}
\end{array}
$$

Dibuat larutan $\mathrm{CCl}_{4}$ 1,3\% sebanyak 1,3 ml yang dilarutkan dalam minyak zaitun sampai dengan $100 \mathrm{ml}$, kemudian diaduk sampai homogen.

\section{Perhitungan Dosis}

Perhitungan dosis untuk kelompok 1: (untuk berat rata - rata mencit $20 \mathrm{~g}$ ). $0,5 \mathrm{mg} / \mathrm{g} \mathrm{BB}$ $\mathrm{X} 20 \mathrm{~g}=10 \mathrm{mg}$ ekstrak etil asetat buah dewandaru. Pemakaian untuk 1 kelompok (terdiri dari 5 ekor ) : $10 \mathrm{mg}$ x 5 × $7=350 \mathrm{mg}$ ekstrak etil asetat buah dewandaru. (NB: perhitungan dosis disesuaikan dengan $\mathrm{BB}$ permencit).

Perhitungan dosis untuk kelompok 2: (untuk berat badan mencit $20 \mathrm{~g}$ ). $1 \mathrm{mg} / \mathrm{g} \mathrm{BB} \mathrm{X} 20$ gr = $20 \mathrm{mg}$ ekstrak etil asetat buah dewandaru.

Pemakaian untuk 1 kelompok ( terdiri dari 5 ekor ) : $20 \mathrm{mg}$ x 5 x $7=700 \mathrm{mg}$ ekstrak etil asetat buah dewandaru. Jumlah ekstrak etil asetat buah dewandaru yang diperlukan untuk berat rata - rata mencit : $350 \mathrm{mg}+700 \mathrm{mg}=1.050 \mathrm{mg}$. (NB: perhitungan dosis disesuaikan dengan $\mathrm{BB}$ permencit).

\section{Perlakuan Terhadap Hewan Percobaan}

Mencit diadaptasi dengan lingkungan penelitian selama 3 hari. Mencit sebanyak 15 ekor dikelompokkan menjadi 3 kelompok, masingmasing kelompok terdiri dari 5 ekor mencit. Kelompok terdiri dari kelompok kontrol negatif dan kelompok perlakuan yang diberikan ekstrak etil asetat buah dewandaru dosis $0,5 \mathrm{mg} / \mathrm{g} \mathrm{BB}$ dan dosis $1 \mathrm{mg} / \mathrm{g} \mathrm{BB}$.

Kelompok kontrol positif diberi $\mathrm{CCl}_{4}$ 1,3 $\%$ selama 7 hari pada hari ke 4 , kemudian diberi $\mathrm{CCl}_{4}$ 1,3\% dan ekstrak etil asetat buah dewandaru dengan dosis $0,5 \mathrm{mg} / \mathrm{g} \mathrm{BB}$ sebanyak $1 \mathrm{ml}$ secara bersamaan selama 7 hari, diberi $\mathrm{CCl}_{4} 1,3 \%$ dan ekstrak etil asetat buah dewandaru dengan dosis 1 $\mathrm{mg} / \mathrm{g}$ BB sebanyak $1 \mathrm{ml}$ secara bersamaan selama 7 hari.

Pada hari ke- 11 mencit dikorbankan dan dibedah untuk diambil hatinya. Hati yang sudah dibedah disimpan dalam larutan buffer formalin $10 \%$. Pemeriksaan mikroskop jaringan hati dibuat sediaan histopatologi di Laboratorium Patologi Fakultas Kedokteran Hewan Universitas Udayana dan selanjutnya dilakukan perbandingan gambaran histopatologi organ hati mencit kontrol dan perlakuan. Perubahan yang diamati yaitu terjadinya kerusakan degenerasi lemak dan nekrosis pada hati mencit. 


\section{HASIL DAN PEMBAHASAN}

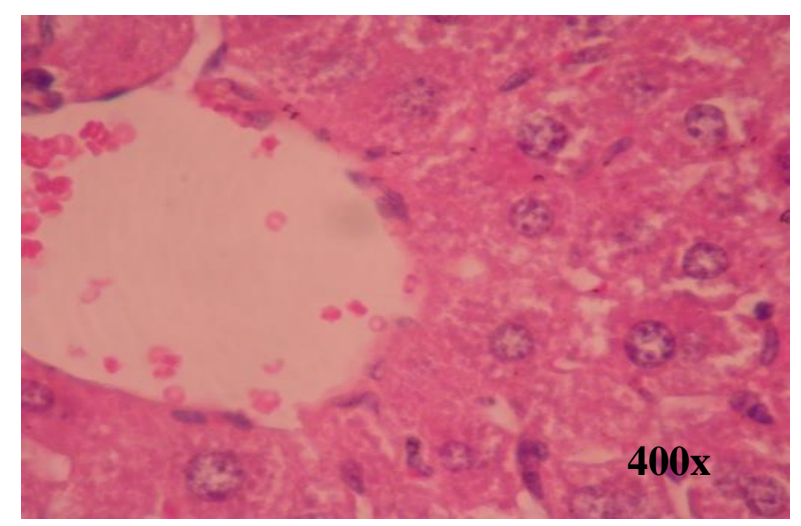

Gambar 1.. Penampang melintang hepar kelompok kontrol. Perbesaran: 400x. Pewarnaan: HE.

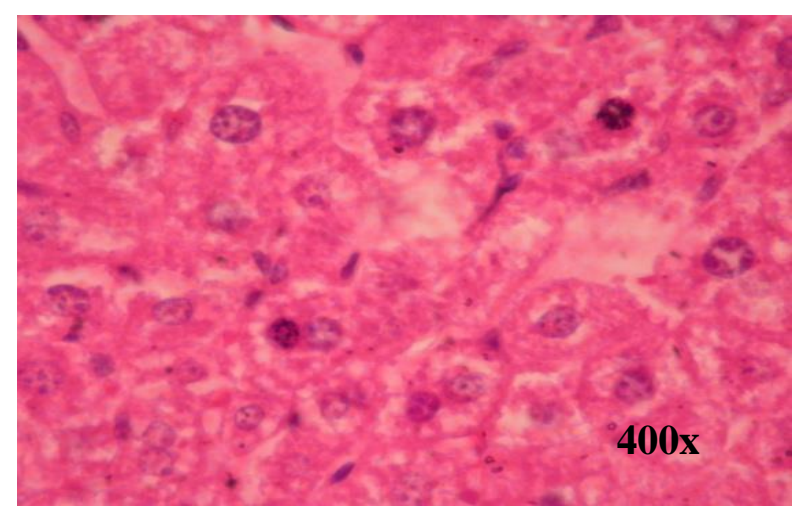

Gambar 2.. Penampang melintang hepar kelompok perlakuan dosis 0,5 mg/gBB. Perbesaran: 400x. Pewarnaan:HE.

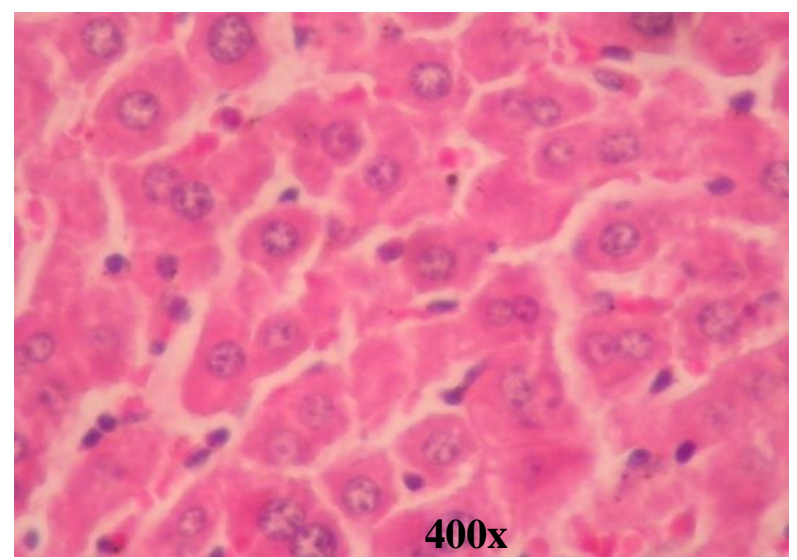

Gambar 3.. Penampang melintang hepar kelompok perlakuan dosis $1 \mathrm{mg} / \mathrm{g}$ BB. Perbesaran: 400x. Pewarnaan:HE.

Dalam penelitian ini telah dilakukan pemeriksaan histopatologi hati mencit setelah diinduksi karbon tetraklorida dan diberikan ekstrak etil asetat buah dewandaru. Sebelum diberikan perlakuan mencit diadaptasi selama 3 hari dan mencit dipuasakan 18 jam dan air minum tetap diberikan agar mencit tidak mengalami dehidrasi.
Mencit dikelompokan menjadi 3 kelompok, setiap kelompok terdiri dari 5 ekor. Setiap kelompok mencit diberikan karbon tetraklorida 1,3\% dengan volume pemberian $0,5 \mathrm{ml}$ selama 7 hari. Kelompok perlakuan yaitu kelompok yang diberikan ekstrak etil asetat buah dewandaru. Kelompok perlakuan I dan II diberikan ekstrak etil asetat buah dewandaru dosis $0,5 \mathrm{mg} / \mathrm{g}$ BB dan $1 \mathrm{mg} / \mathrm{g}$ BB sebanyak $1 \mathrm{ml} / \mathrm{g}$ BB selama 7 hari.

Pada hari ke-11 mencit dikorbankan dan dibedah untuk pengambilan hati dan dilakukan pembuatan preparat histopatologi dengan pewarnaan HE (Hematoxilin-Eosin), setelah itu dilakukan pengamatan dengan mikroskop. Pengamatan dengan mikroskop dilakukan secara kualitatif terhadap gambaran histopatologi. Pada kelompok kontrol negatif menunjukkan karbon tetraklorida $1,3 \%$ dalam 7 hari telah merusak jaringan hati mencit yang ditunjukkan adanya gambaran degenerasi melemak dan nekrosis. Tampak terlihat degenerasi melemak yang ditandai dengan adanya vakuola-vakuola besar berwarna putih. Menurut moslen (2001) timbunan lemak dalam sel hepar membentuk vakuola kecil-kecil tetapi tidak sampai mendesak inti. Keadaan seperti ini disebut degenerasi perlemakan mikrovesikuler. Apabila vakuola-vakuola bergabung membentuk vakuola yang lebih besar dan hampir semua hepatosit terisi butiran lemak berukuran besar maka akan mendorong inti sel ke daerah perifer. Perlemakan dengan vakuola berukuran besar disebut sebagai perlemakan makrovesikuler. Secara histologi dalam teknik embeding parafin standar hepatosit yang mengandung lemak akan tampak sebagai vakuola kosong atau berwarna putih yang mendesak inti sel ke arah perifer(Sulistianto, dkk,2004). Steatosis makrovesikuler menunjukkan gradasi beratnya cedera berupa perlemakan yang dapat disebabkan oleh $\mathrm{CCl}_{4}$. Karbon tetraklorida menyebabkan peroksidasi lemak dan merusak struktur serta fungsi retikulum endoplasmik, sehingga terjadi perlemakan (steatosis) oleh karena itu, kerusakan tranpor lemak oleh lipoprotein(Lintong, 2013). Nekrosis yang ditemukan pada hati mencit kelompok kontrol adalah jenis kariorheksis (pecahnya inti menjadi beberapa bagian). Terjadinya karioreksis disebabkan karena desakan vakuola semakin kuat, membran inti akan pecah diikuti inti yang mengalami fragmentasi (Sulistianto dkk., 2004). Pada gambaran histopatologi kelompok yang diberikan perlakuan ekstrak etil asetat buah dewandaru dosis $0,5 \mathrm{mg} / \mathrm{g}$ BB masih ditemukan adanya degenarasi melemak dan nekrosis, sedangkan dosis $1 \mathrm{mg} / \mathrm{g} \mathrm{BB}$ sudah 
tidak ditemukan adanya degenarasi melemak dan nekrosis. Degenerasi melemak pada kelompok perlakuan ditunjukkan dengan adanya vakuolavakuola yang lebih kecil jika dibandingkan dengan kelompok kontrol. Hal ini menunjukkan adanya perbedaan degenerasi melemak antara kelompok kontrol dan kelompok perlakuan yang diberi ekstrak etil asetat buah dewandaru. Nekrosis pada histopatologi hati kelompok perlakuan yang diberikan ekstrak etil asetat buah dewandaru tidak menunjukkan adanya perubahan dibandingkan dengan kelompok kontrol. Nekrosis yang terjadi disebabkan karena karbon tetraklorida di dalam tubuh dimetabolisme oleh enzim sitokrom P. 450 dan menghasilkan radikal bebas triklorometil yang menyebabkan proses autooksidasi dan menghasilkan radikal lipid yang tidak stabil, selanjutnya akan mengakibatkan peroksidasi lipid. Peroksidasi lipid dapat menyebabkan kerusakan membran sel, kerusakan mitokondria, denaturasi protein sel dan akhirnya terjadi kematian sel (Sativa, 2006).

Adanya perubahan pada degenerasi melemak antara kelompok kontrol dan kelompok perlakuan kemungkinan disebabkan oleh adanya zat antioksidan seperti flavonoid (Supratanda, dkk.,, 2014). Mekanisme antioksidan yang mungkin terjadi pada kelompok perlakuan adalah menetralisir senyawa radikal bebas dari karbon tetraklorida dan mencegah terjadinya reaksi berantai dengan cara mendonorkan elektronnya kepada radikal bebas triklorometil dan triklorometil peroksil sehingga menjadi stabil. Selain itu antioksidan akan mengurangi oksidatif lebih lanjut dari asam lemak pada fosfolipid sehingga regenerasi dari sel hati yang telah mengalami cedera dapat berlangsung lebih cepat (Tappi, 2013).

Dari hasil pengamatan efek ekstrak etil asetat buah dewandaru untuk melindungi hati mencit, hanya sebagian terlihat adanya perubahan pada kerusakan hati mencit yaitu nekrosis. Hal ini mungkin dikarenakan waktu pengamatan yang pendek belum mampu sepenuhnya menghilangkan nekrosis pada histopatologi hati mencit yang cedera akibat $\mathrm{CCl}_{4}$, ataupun dosis yang diberikan belum efektif untuk membuat efek protektif yang signifikan. Dengan demikian, ekstrak etil asetat buah dewandaru masih berpotensi untuk dibuktikan khasiat hepatoprotektornya secara ilmiah melalui penelitian lebih lanjut.

\section{SIMPULAN}

Dari hasil penelitian dapat disimpulkan bahwa gambaran histopatologi hati mencit yang diinduksi karbontetraklorida dan diberikan ekstrak etil asetat buah dewandaru dapat mengurangi degenerasi melemak dengan memperkecil vakuola-vakuola lemak didalam sitoplasma sel hati. Namun, nekrosis pada kelompok kontrol dan kelompok perlakuan ekstrak etil asetat buah dewandaru sudah sebagian menunjukkan adanya perubahan pada sel hati mencit.

\section{DAFTAR PUSTAKA}

Amirudin, Rifai. (2007). Fibrosis Hati dalam Buku Ajar Ilmu Penyakit Hati Ed 1. Jakarta: Jayabadi. h: 329-332.

Einbond, L., Kurt A., Reynertson, Xiao-Dong, L., Margaret J. Basile, Edward, J. \& Kennelly, (2004). Anthocynin antioxidats from edible fruit. J. Food Chem, 84, 23-28

Fouw, J. D., \& World Health Organization. (1999). Carbon tetrachloride. World Health Organization.

Gibson, N. E. (2014). Efek Hepatoprotektor Ekstrak Etanol Lidah Buaya(Aloe vera Linn.) Terhadap Gambaran Histopatologi Hati Tikus Jantan Putih ( Rattus norvegicus ) Galur Wistar yang Diinduksi Parasetamol. Skripsi, (Pontianak, Fakultas Kedokteran, Universitas Tanjungpura).

Guyton A. C., Hall J. E. (1997). Buku Ajar Fisiologi Kedokteran. Edisi 9. Jakarta: EGC.

Hadi, S. (2002). Sirosis Hepatis dalam Gastroenterologi. Bandung: Alumni. pp, 637638.

Hutapea, J. R. (1994). Inventaris tanaman obat Indonesia. Jilid III, Departemen Kesehatan RI dan Badan Penelitian dan Pengembangan Kesehatan, 29-30.

Kardena, I. M., \& Winaya, I. B. O. (2011). Kadar Perasan Kunyit yang Efektif Memperbaiki Kerusakan Hati Mencit yang Dipicu Karbon Tetrachlorida. Jurnal Veteriner, 12(1), 34-39.

Khotimah, K. D. S. (2004). Uji Aktivitas Antibakteri Ekstrak Kloroform dan Metanol Daun Dewandaru (Eugenia Uniflora. L.) Terhadap Staphyloccus Aureus. Shigella 
Dysentriae dan Escherichia Coli, Skripsi, Fakultas Farmasi, Universitas Muhamadiyah Surakarta: Surakarta.

Klaassen, C. D. (1981). Pharmacokinetics in metal toxicity. Fundamental and Applied Toxicology, 1(5), 353-357.

Lembaga Ilmu Pengetahuan Indonesia. (2015). UPT Balai Konservasi Tumbuhan Raya "Eka Karya" Bali.

Nurdjaman, Soetedjo, \& A, I. (2001). Histologi: kelenjar pencernaan hepar dan vesika felea. Badan Penerbit Universitas Diponegoro.

Oliveira, M. D. L., Andrade, C. A. S., SantosMagalhães, N. S., Coelho, L. C. B. B., Teixeira, J. A., Carneiro-da-Cunha, M. G., \& Correia, M. T. S. (2008). Purification of a lectin from Eugenia uniflora L. seeds and its potential antibacterial activity. Letters in applied microbiology,46(3), 371-376.

Onwudiwe, Njoku, \& Joshua. (2010). Phytochemical Analysis and Acute Toxicity/Lethaly Study of Ethanol Extract of
Eugenia Uniflora Pulp. Journal of Pharmacognosy and Phytochemistry, 2(4), 356-339.

Santos, A. K. L., Costa, J. G. M., Menezes, I. R. A., Cansanção, I. F., Karla, K. A., Matias, E. F. F., \& Coutinho, H. D. M. (2010). Antioxidant activity of five Brazilian plants used as traditional medicines and food in Brazil, 6(24), 335-338. http://doi.org/10.4103/0973-1296.71789

Suhendi, A., Sjahid, L. R., \& Hanwar, D. (2011). Isolasi dan Identifikasi Flavonoid dari Daun Dewandaru (Eugenia Uniflora L). Fakultas Farmasi, Universitas Muhammadiyah Surakarta, 12(2).

Utami, W., Dai, M., \& Sofiana, Y. R. (2005). Aktivitas penangkap radikal dengan metode DPPH serta penetapan kandungan fenol dan flavonoid dalam ekstrak kloroform, ekstrak etil asetat, ekstrak etanol daun dewandaru (Eugenia uniflora L.). Pharmaceutical Journal of Indonesia, 6, 5-9. 